\title{
Mapping the karstification potential of central Cebu, Philippines using GIS
}

Regina Martha Lumongsod ( $\square$ rglumongsod@up.edu.ph )

University of the Philippines Diliman https://orcid.org/0000-0001-6369-1855

Noelynna Ramos

University of the Philippines Diliman

Carla Dimalanta

University of the Philippines Diliman

\section{Research Article}

Keywords: karstification potential, karst features, raster overlay analysis, GIS

Posted Date: February 15th, 2022

DOI: https://doi.org/10.21203/rs.3.rs-1263655/v1

License: (1) This work is licensed under a Creative Commons Attribution 4.0 International License.

Read Full License 


\section{Mapping the karstification potential of central Cebu, Philippines using GIS}

Regina Martha G. Lumongsod ${ }^{1 *}$, Noelynna T. Ramos ${ }^{1}$, and Carla B. Dimalanta ${ }^{1}$

${ }^{1}$ National Institute of Geological Sciences, College of Science, University of the Philippines, Diliman, Quezon City, 1101 Philippines

*corresponding author: rglumongsod@up.edu.ph

\section{Abstract}

Karstification is influenced by numerous factors, such as climate, geomorphology, and anthropogenic processes. Karstified areas are usually faced with numerous karst-related problems such as sinkhole formation, ground subsidence, and groundwater vulnerability. We evaluated the karstification potential of central Cebu, Philippines using Raster Overlay Analysis (ROA) in a geographic information system (GIS) platform. Raster Overlay uses multiple thematic maps which represent the different factors affecting karstification. Thematic factors include precipitation, temperature, vegetation density, elevation, slope, drainage density, lineament density, and geology. These factors were then correlated with the generated karstification potential map using the Cell Statistics tool. ROA reveals that more than $65 \%$ of central Cebu has low to moderate karstification potential. Areas with moderate to very high karstification potential coincide with locations of nine known caves. Cell Statistics reveal that the karstification potential map is strongly correlated with precipitation and is least correlated with drainage density. Information on the karstification of an area underlain by highly soluble bedrock is beneficial to effective land use planning and reduction of hazards related to karst degradation and collapse.

Keywords: karstification potential, karst features, raster overlay analysis, GIS 


\section{Environmental Earth Sciences}

\section{1. Introduction}

Karstification is the process by which highly soluble bedrock such as carbonates and evaporites are dissolved through the chemical and mechanical action of water (Monroe, 1970). This dissolution process leads to the formation of a distinct topography known as karst terrain, which is characterized by geomorphological landforms such as caves, subterranean rivers, pinnacle karst, and sinkholes. Karstification can occur at any latitude and elevation, allowing karst topography to be found anywhere in the world (Cahalan and Milewski, 2018). Around 20\% of the Earth's landscapes are karstic (Ford and Williams, 1989). In the Philippines, around $10 \%$ of the land area is karst (Wagner, 2013). This is manifested through a multitude of karst features that can be found in the archipelago, some of which have been developed into tourist destinations and protected areas (e.g., Puerto Princesa Subterranean River National Park in Palawan, Chocolate Hills in Bohol, and the karst towers in El Nido, Palawan). Hazards associated with karst features such as sinkhole collapse and land subsidence have also occurred in the country. A notable instance is the appearance of close to 100 sinkholes in Bohol following the $2013 \mathrm{M}_{\mathrm{w}} 7.2$ Bohol earthquake, some of which have engulfed whole houses (Matus, 2013). Aside from these, groundwater in karst areas is also prone to pollution and contamination (Brinkmann and Parise, 2012).

Several factors influence the degree and potential of karstification in an area. Ford and Williams (1989) used the term "karst denudation" to pertain to the dissolution of carbonates or evaporites through chemical and mechanical means resulting to karst topography. Karst denudation rates are generally affected by climate, geology, and geomorphology (Ford and Williams, 1989). Differences in the relative influence of each factor can also result to variations in denudation rate. The relative influence of 
1 each factor differs spatially, making karstification studies site-specific in general

2 (Wilson and Beck, 1992). In order to evaluate the relative degree of influence of each

3 factor, geospatial methods are employed through geographic information system

4 (GIS) (Hubbard, 2001; Shofner et al., 2001; Farrant and Cooper, 2008; Doctor and

5 Doctor, 2012).

$6 \quad$ Numerous karst studies have already been conducted by several authors

7 around the world, most of which are concentrated on cave networks, sinkhole

8 occurrence, and groundwater systems (Whitman et al., 1999; Hung et al., 2002;

9 Bakalowicz, 2005). With the advent of modern methods on geomorphological studies,

10 karst studies commonly utilize remote sensing and GIS tools that are sometimes

11 accompanied by little to no field validation. Seif and Ebrahimi (2014) used GIS

12 modelling and introduced a karstification index in order to evaluate the degree of

13 karstification of carbonate rocks in Iran; this study concentrated on outcropping

14 carbonate rocks and used higher resolution data (e.g., LiDAR) than previous studies

15 on the same area. Moradi and others (2016) used fuzzy logic and analytical hierarchy

16 process (AHP) models to map the karstification potential of northeastern Khuzestan

17 Province in Iran. Both studies are concentrated on a semi-arid to semi-humid environment, with landscapes that have barren to little vegetation. Both studies are also aimed towards the understanding of karst development as well as looking into the groundwater potential of the area. An easier approach, however, can also be used in dealing with raster data, especially if rankings cannot be given. Simple raster addition or other mathematical operations applied in local scale have been previously proven as sufficient (Dumperth et al., 2016).

In this study, the karstification potential of central Cebu (Figure 1), a tropical 
1 (ROA) in GIS. Thematic layers corresponding to various factors affecting karstification

2 are used (i.e., elevation, slope, lineament density, drainage density, precipitation,

3 temperature, geology, and vegetation density). The resulting karstification potential

4 map provides insights as to where most of the karst features can be found or

5 developed in the area. It also shows which factors have a stronger influence on karst

6 denudation. Karstification potential maps can be used as a valuable tool in land use

7 and urban planning to avoid or mitigate the hazards that result from a karstic

8 landscape.

9 2. Study area

10 Cebu is one of the Visayan Group of Islands located in central Philippines

11 (Santos-Yñigo, 1951). It is an island that trends northeast-southwest, and was

12 regarded as a large anticline whose stratigraphy and structure is representative of the

13 Visayan Basin (Rangin et al., 1989). Consequently, central Cebu is characterized by

14 a mountainous middle region (termed as central highlands) with younger strata found

15 closer and dipping towards the coast (Santos-Yñigo, 1951) (Figure 1). Central Cebu

16 is the most lithologically diverse part of Cebu Island. Basement rocks of Cretaceous

17 age can be found juxtaposed with younger Cenozoic formational units (Santos-Yñigo,

18 1951; Müller et al., 1989). This distinct configuration of formations with varying ages

19 (i.e., very old units with very young units) is the product of the complex tectonic history

20 of the Visayan Basin and the Negros Volcanic Arc (Rangin et al., 1989). Due to uplift

21 caused by anticline formation and subsequent erosion, the older basement units were exposed in central Cebu. Sea-level changes, especially during Middle Oligocene to

23 Pleistocene, allowed the deposition of the younger sedimentary units (Müller et al., 24 1989). 


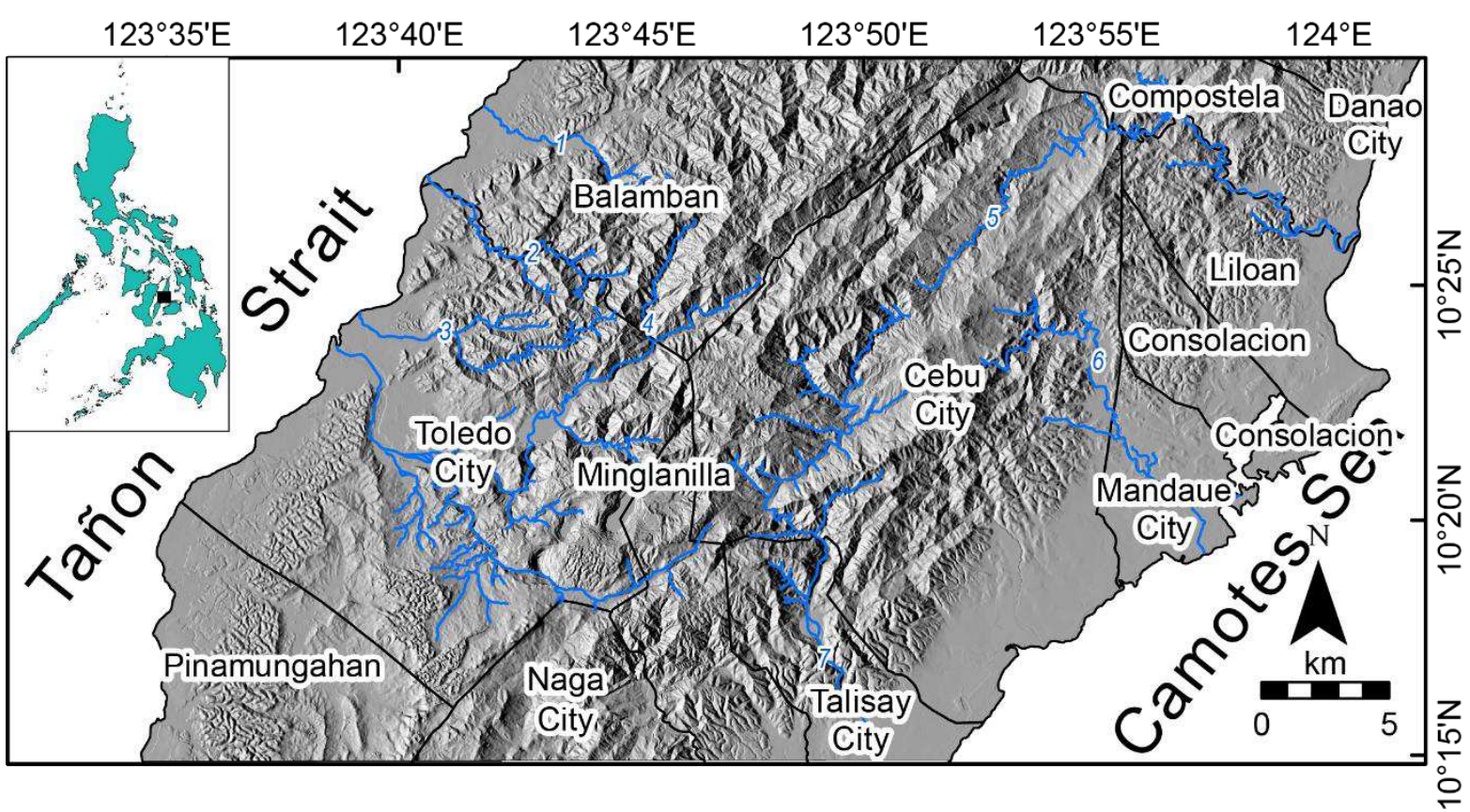

2 Figure 1. Location map of the study area in central Cebu. The central Cebu highlands

3 is a major physiographic feature at the central part of the study area (IFSAR: NAMRIA).

4 Blue lines represent the major streams: 1 - Abucayan River, 2 - Maingit River, 3 -

5 Talavera River, 4 - Sapangdaku River, 5 - Cotcot River, 6 - Butuanon River, 7 -

6 Mananga River (NAMRIA). Inset map shows the location of central Cebu as part of

$7 \quad$ Cebu Island in central Philippines.

More than $70 \%$ of Cebu Island is underlain by sedimentary formations, most of which are carbonate-bearing (Porth et al., 1989) (Figure 2); only the central part of the island and nearby municipalities are underlain by non-sedimentary rocks such as schists, diorites, and volcanic rocks. Unlike most areas of karstification potential studies, karst landscapes in Cebu are commonly covered with dense vegetation.

The resulting drainage pattern of the area is dendritic to trellis, which is due to the fault and fold structures that are manifestations of the formation of the anticlinorium (Figure 1). The major fault system in the study area is the Central Cebu Fault System

16 (Philippine Institute of Volcanology and Seismology [PHIVOLCS], 2017). Major 17 streams include Abucayan River, Maingit River, Talavera River, and Sapangdaku 
1 River, which drain into the Tañon Strait in the west; and Cotcot River, Butuanon River,

2 and Mananga River which drain into the Camotes Sea in the east (Figure 1). The 3 easternmost areas of central Cebu are vast reclaimed lands which include parts of 4 Cebu City, Mandaue City, and Talisay City.

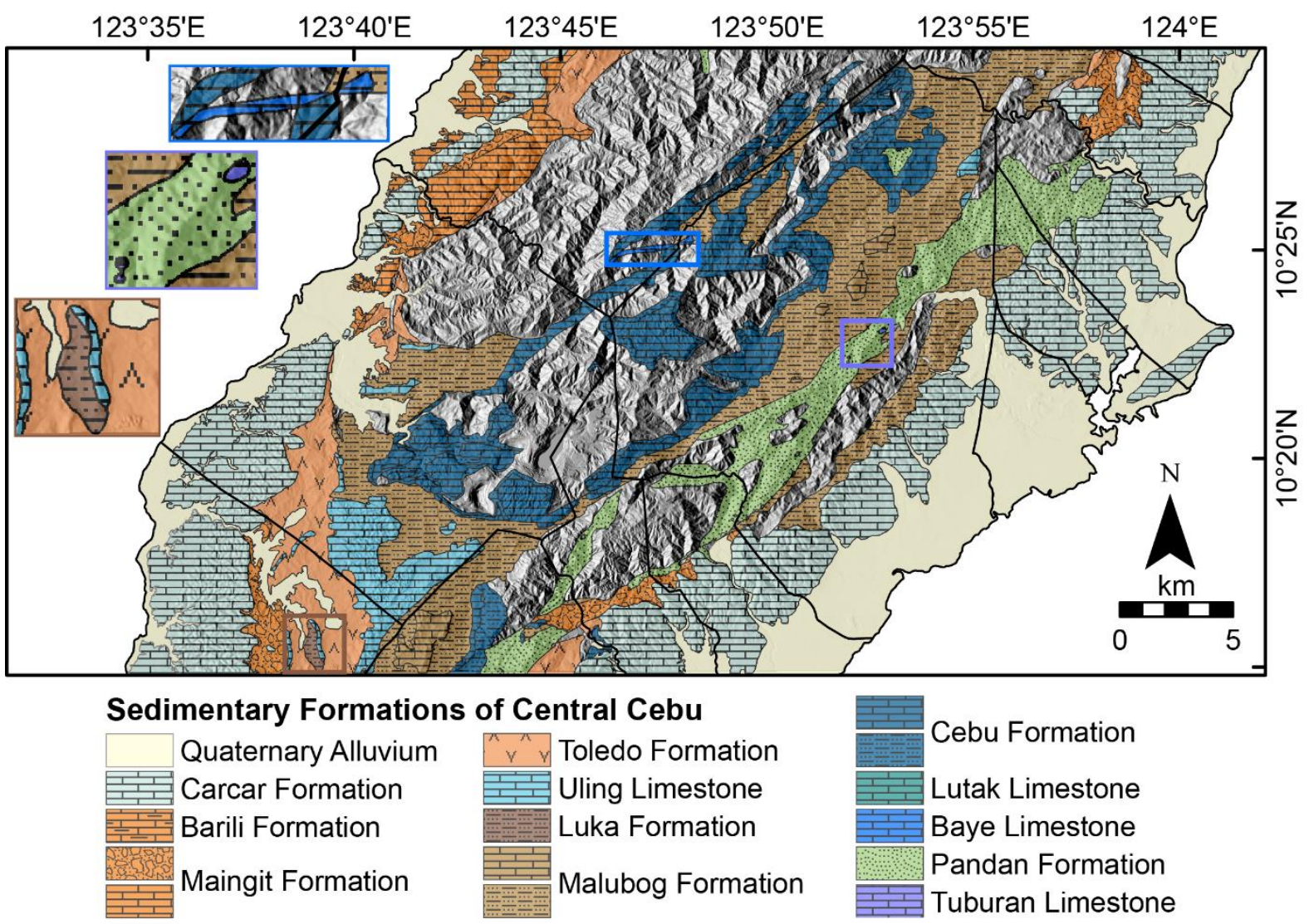

6 Figure 2. Geologic map of central Cebu (modified from BMG, 1985, 1983a, 1983b, 1983c, 1983d) showing the different sedimentary formations in the area (Basemap: IFSAR from NAMRIA). Inset pictures show sedimentary formations with little exposure:

9 Baye Limestone (top), Tuburan Limestone (middle), and Luka Formation (bottom).

Due to its vast karst landscapes, karst features such as caves and sinkholes are common in the island. Cebu currently faces karst-related phenomena such as sinkhole collapse and water scarcity (Leyson, 2017; Mondragon and Erram, 2018). Most of Cebu Island's population, furthermore, is in its central area, since it also 14 includes its capital, Cebu City (Philippine Statistics Authority [PSA], 2016). 


\section{3. Analysis of factors promoting karstification}

Raster Overlay Analysis involves the manipulation of raster data through different

3 GIS toolsets in order to extract information on elevation, slope, lineament density,

4 among others (Environmental Systems Research Institute [ESRI], 2016). The Raster

5 calculator, under the Spatial Analyst toolbox in ArcGIS, executes different

6 mathematical operations (Map Algebra) given multiple raster datasets (ESRI, 2016).

7 In this study, several factors from available and published sources (Table 1) were

8 reclassified into five categories (very high to very low) based on their general influence

9 on karstification and added through Raster calculator (Figure 3) in order to generate a

10 karstification potential map of central Cebu. Vector data layers were converted into

11 raster through Rasterization so they can be inputted into the Raster calculator

12 expression.

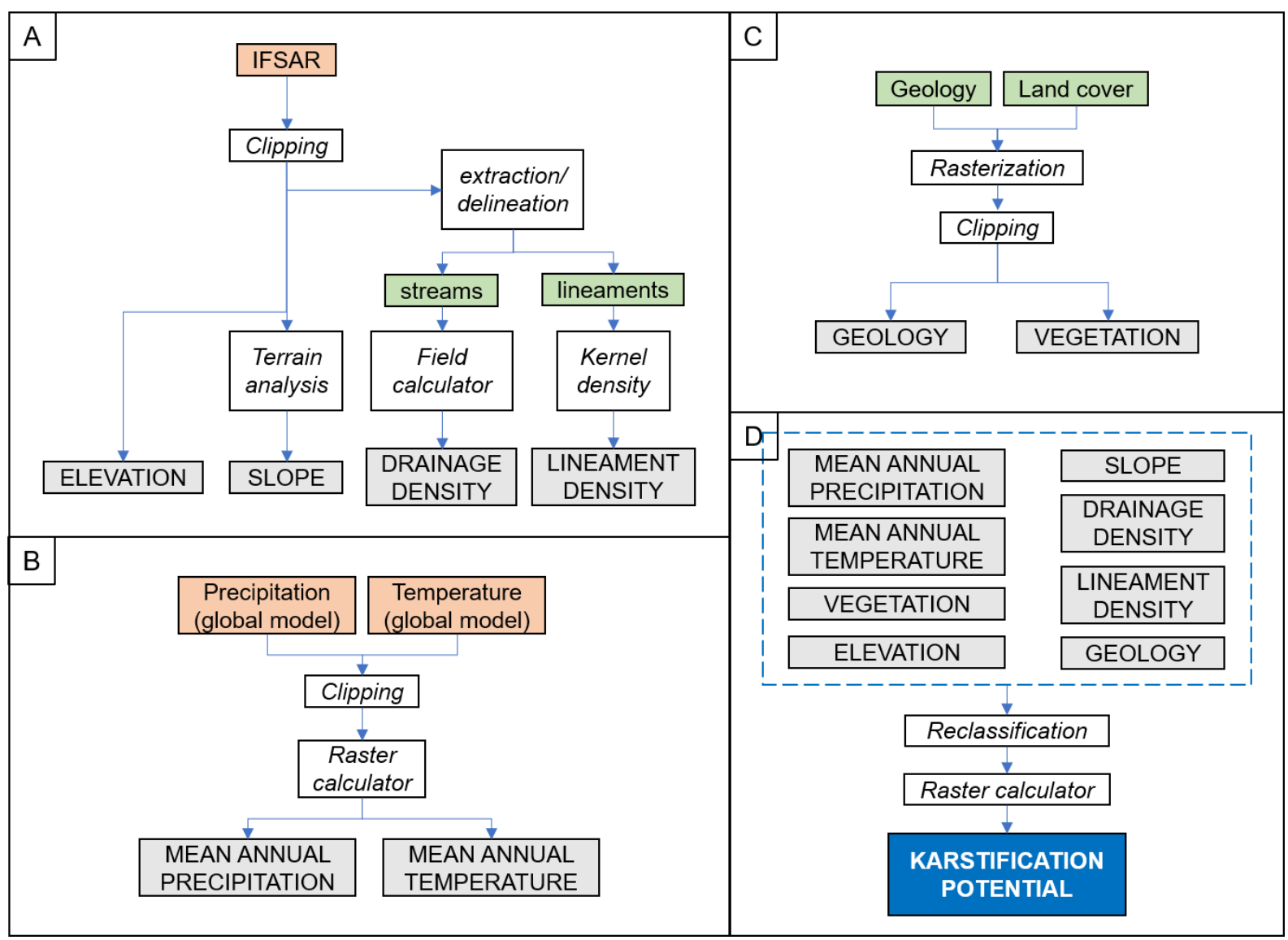

14 Figure 3. Flowchart of methods used in this study. Raster files are highlighted in 
1 orange while vector files are highlighted in green. GIS-based processes are italicized,

2 and thematic layers are highlighted in gray. (A) IFSAR-derived data were subjected to

3 Clipping, Terrain analysis, Field calculator, and Kernel density to yield the elevation,

4 slope, drainage density, and lineament density maps, respectively. (B) Both mean

5 annual precipitation and mean annual temperature were calculated from global model

6 raster file by Hijmans and others (2005). (C) Vector files geology and land cover were

7 rasterized first. (D) All the thematic maps generated from the previous processes were subjected to Reclassification into five categories (very high to very low).

The different thematic layers corresponding to the various factors are subsets of the following major factors: climate, vegetation, topography, geomorphology, and geology. Each layer is reclassified from 1 to 5 , wherein higher values reflect conditions that positively induce karst denudation following the classification of Farrant and Cooper (2008), Green (2015), and Moradi and others (2016). After reclassification, the layers were added using Raster calculator (Figure 3). Higher values reflect areas with higher karstification potential. The karstification potential map was then compared with previous studies and locations of existing karst features to check its validity. Cell Statistics (Range) was then used to compare each factor layer with the output karstification potential values to determine relative correlation.

\subsection{Climate}

Climate data used in this study are precipitation and temperature. Higher rainfall, which is related to higher elevations and lower temperatures, has been identified as conducive to karst development (Santo et al., 2007; Green, 2015), since water action is needed for dissolution. Cebu Island belongs to the largest climate group in the Philippines, which has a relatively flatter seasonal cycle and an average rainfall 
1 peak of $230 \mathrm{~mm}$ during July to October (Corporal-Lodangco and Leslie, 2017).

2 Precipitation (Figure 4A) and temperature (Figure 4B) data were averaged and clipped

3 from the average monthly data from $1970-2000$ by Fick and Hijmans (2017).

We added the 12 average monthly precipitation datasets to obtain a mean annual precipitation layer (in $\mathrm{mm} / \mathrm{yr}$ ). The same procedure was applied on 12 average mean temperature datasets to yield a mean annual temperature layer (in ${ }^{\circ} \mathrm{C}$ ). Both layers were then reclassified into five categories (very high, high, moderate, low, very low) based on manually adjusted equal interval classification of the data (Table 2).

Equal interval classification divides the data into equal-sized subranges and is used for data with familiar ranges, such as temperature. Equal interval is also recommended to give emphasis to value differences if the values in the data are evenly distributed (ESRI, 2016). The precipitation and temperature maps of central Cebu appear very similar in distribution but exhibit an inverse relationship. Precipitation is highest in the central areas and decreases towards the coast. Temperature is lowest in the central areas and increases towards the coast. Precipitation and temperature play opposite roles when it comes to karstification potential. Higher precipitation leads to higher infiltration, yielding higher karstification potential. Heavy rainfall may also lead to sinkhole collapse, further favoring karstification (Green, 2015). Lower temperature has been previously linked to higher karstification potential (Moradi et al., 2016).

\subsection{Vegetation}

Vegetation cover (Figure $4 \mathrm{C}$ ) is obtained through the reclassification of the 2010 land cover vector file from the National Mapping and Resource Information Authority (NAMRIA) into five categories (very sparse, sparse, moderate, dense, very dense; Table 3). Very dense areas correspond to areas classified as closed forests and mangrove forests. Dense areas correspond to areas classified as open forests. 


\section{Environmental Earth Sciences}

1 Moderate areas correspond to areas classified as grasslands or shrubs. Sparse areas

2 correspond to areas classified as cultivated. Very sparse areas correspond to barren

3 land, inland water, built-up areas, or fishponds. Vegetation cover has been used by

4 Moradi and others (2016) as a proxy for infiltration, wherein denser vegetation begets

5 higher infiltration, leading to high karstification potential. In tropical areas, higher

6 vegetation density is also linked with karst terrain development, since denser

7 vegetation is conducive for near-surface percolation, allowing groundwater to be

8 stored in karst bedrock that is nearer to the surface (Chenoweth, 2003; Moradi et al., 9 2016).

\subsection{Topography}

Topographic data, comprising of elevation and slope, were extracted from a 5-

m resolution Interferometric Synthetic Aperture Radar (IFSAR)-derived digital elevation model (DEM) from NAMRIA. Elevation does not directly influence karstification, but has been used as a proxy for rainfall, recharge, and hydraulic gradient; karstification potential is increased with increased elevation in a region since rainfall and groundwater recharge are also increased (Berhanu and Hatiye, 2020; Moradi et al., 2016). Flat slopes are also conducive for karst denudation since a lower slope gradient allows concentration, and therefore dissolution, in certain areas (Farrant and Cooper, 2008; Green, 2015). However, this can also hinder karst erosion which is more prevalent in steep slopes (Santo et al., 2007). The elevation map (Figure 4D) was reclassified into five categories based on the manually adjusted equal interval classification of values, as there is no basis on how to classify elevation data with respect to elevation, but the elevation values in the area are well distributed (Table 2). The slope map (Figure 4E) was also reclassified into five categories (Table 2), where very low/flat slope corresponds to areas with less than $5^{\circ}$ slope while very high/steep 
1 slope corresponds to areas with greater than $35^{\circ}$ slope (e.g., Green, 2015).

\subsection{Geomorphology}

Geomorphology data include lineament density and drainage density. The presence of lineaments, which contribute to secondary porosity and higher permeability, is also associated with karst formation and development (Brook and Allison, 1986; Doctor et al., 2008; Faivre and Pahernik, 2008). Lineament density was calculated from the average frequency of lineaments in the area, which was generated using the Kernel Density Tool, under the Spatial Analyst toolset, in ArcGIS 10.3 (Figure 4F). These lineaments correspond to the different faults delineated during previously conducted field surveys. Drainage density was obtained by dividing the total length of streams by the total area of each drainage basin in central Cebu (Figure 4G). Both streams and drainage basins were extracted and delineated from the IFSAR DEM through automated methods (i.e. Hydrology tools) in ArcGIS 10.3. Both the lineament density and drainage density maps were reclassified into five categories based on equal interval classification (Table 2).

\subsection{Geology}

The main factor leading to karstification is the presence of highly soluble bedrock (i.e., carbonate or evaporite) (Monroe, 1970; Farrant and Cooper, 2008). Limestone, in particular, dissolves more easily if it occurs on its own ("pure") as compared to if it was mixed with other insoluble materials (Sweeting, 1979). This porosity factor, adding to high surficial permeability, is also related to the characteristically poor drainage resulting to low drainage density in karst landscapes (Farrant and Cooper, 2008; Ford and Williams, 2013).

Previous geologic maps of the Mines and Geosciences Bureau (BMG, 1983a, 


\section{Environmental Earth Sciences}

1 1983b, 1983c, 1983d, 1985) were adopted in this study. Rock units were reclassified

2 into five categories: non-sedimentary, clastics only, clastics with limestone, young

3 limestone, and old limestone (Figure 4G; Table 3). Non-sedimentary areas correspond

4 to those underlain by either igneous or metamorphic units, and these were given a

5 value of one (1). Clastic areas pertain to areas that are underlain by sedimentary

6 formations that do not contain limestone, and these were given a value of two (2).

7 Clastics with limestone pertain to areas with both clastic and limestone members, and

8 these were given a value of (3). Young limestone areas pertain to areas underlain by

9 limestone younger than Middle Miocene, and these were given a value of four (4). Old

10 limestone areas pertain to areas underlain by limestone older than Middle Miocene,

11 and these were given a value of 5. Older limestone areas have more developed karst

12 features such as wider, coalesced sinkholes (Lumongsod et al., 2020). 

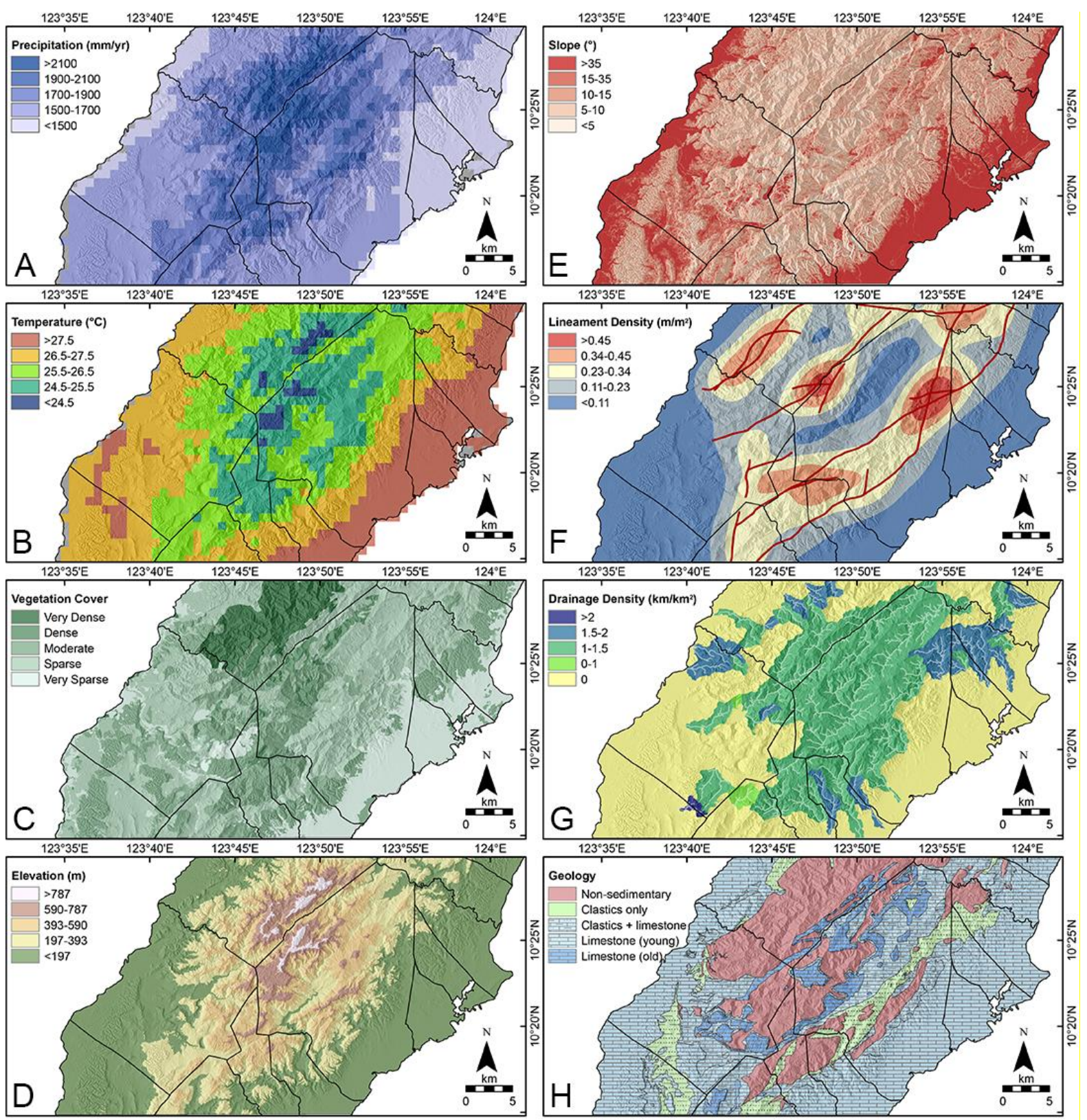

2 Figure 4. Factors promoting karstification include (A) high mean annual precipitation

3 ( $>2100 \mathrm{~mm} / \mathrm{yr})$, (B) low mean annual temperature $\left(<24.5^{\circ} \mathrm{C}\right),(\mathrm{C})$ very dense

4 vegetation, (D) high elevation ( $>787$ masl), (E) gentle slope $\left(<10^{\circ}\right),(F)$ very high

5 lineament density (>0.45; red lines correspond to faults), (G) very low drainage density

6 (0; polygons correspond to drainage basins, white lines correspond to streams), and

7 (H) older limestone bedrock. (IFSAR, Land cover: NAMRIA; Precipitation and

8 temperature: Fick and Hijmans, 2017). 


\section{$1 \quad 4$. Results}

\subsection{Karstification potential map of central Cebu}

The karstification potential map generated from the raster addition of the eight thematic layers (Figure 4) was reclassified into five categories (very high to very low)

5 (Figure 5). The resulting spatial resolution of the map is 30 arc-seconds (approximately $30 \mathrm{~m}$ ), following the lowest resolution datasets. Majority of central Cebu is under low

7 (33.70\%) and moderate (32.45\%) karstification potential while a very small fraction belongs to very high karstification potential (5.95\%). These areas of moderate to very

9 high karstification potential coincide with the presence of known caves, such as

10 Cantipla Cave and Satuhan Cave (Figure 6A-C). The pattern that can be seen in Cebu

11 City (Figure 6A) is comparable with the results of Lumongsod and others (2020), in which more mature sinkholes are observed farther from the coast, as this is where the relatively older karstic formations are.

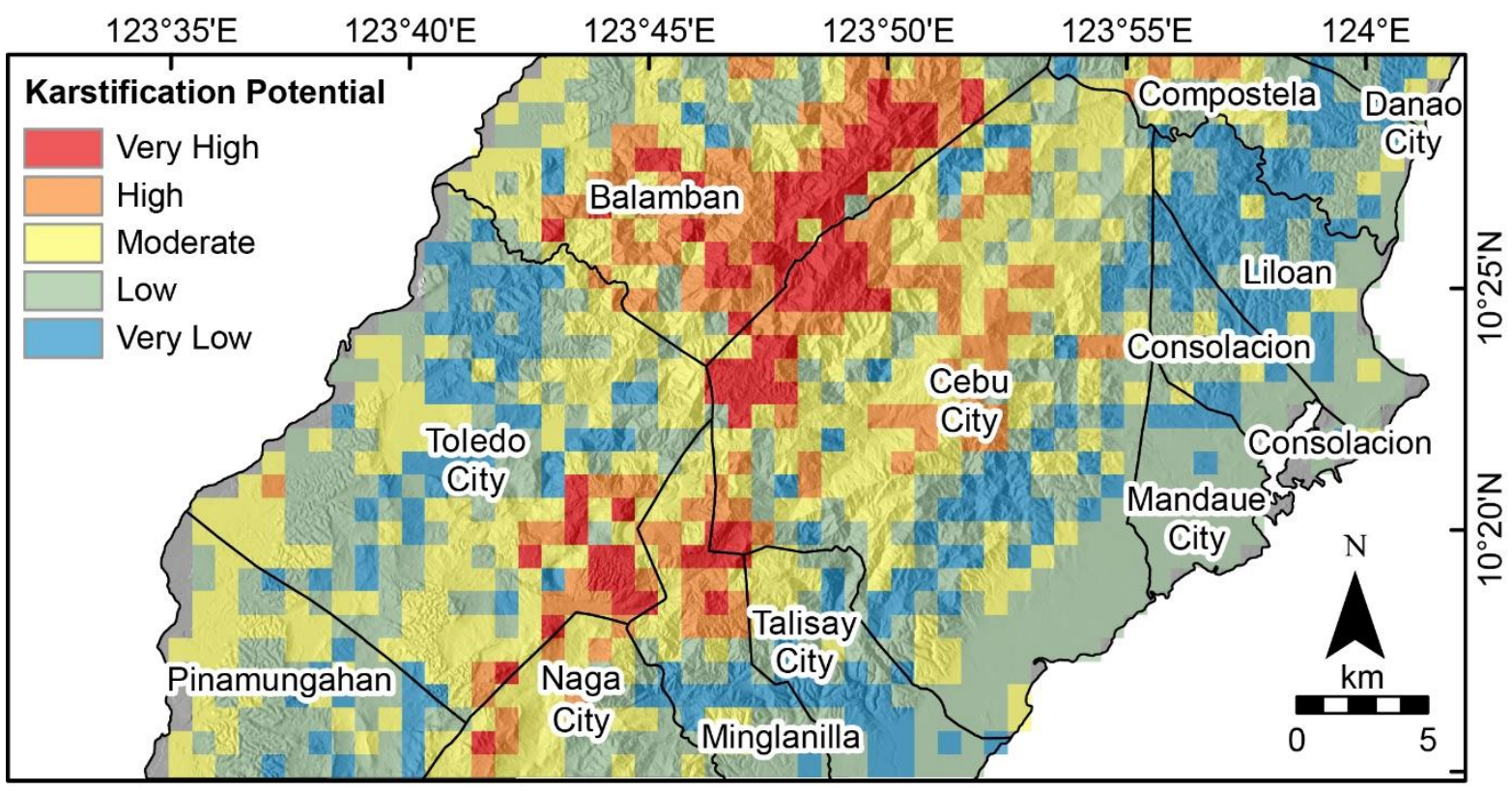

15 Figure 5. Karstification potential map of central Cebu. Very high degrees of karstification can be observed along the central highlands, showing a NE-SW trend.

17 The relative distribution of values (very high to very low) between the karstification 
1 map and the precipitation, temperature, and elevation layers appear to be similar.

In terms of yielded data values, it is observed that the precipitation and

3 temperature layers share the most similarity with the karstification potential map. More

4 than $40 \%$ of the precipitation dataset matches with the cell values in the output

5 karstification potential (Figure 7). The layers which share the least similarity with the

6 karstification potential map are the drainage density (20.41\%) and geology (20.28\%)

7 layers.

\section{Discussion}

Karstification maps highlight either karstification potential or degree of karstification. The resultant map in this study reflects karstification potential since the input values resemble factors promoting dissolution and karst development. Degree of karstification usually refers to the occurrence of persistent karst features such as sinkholes (sinkhole/doline index), caves, or even a network of various features characteristic of a karst landscape.

Central Cebu is dominantly underlain by sedimentary formations, most of which are carbonate bearing (Figure 2; Figure $4 \mathrm{H}$ ). Majority of central Cebu receive moderate to low rainfall (Figure $4 \mathrm{~A}$ ) and is subjected to moderate to high average temperature (Figure 4B). Only a small portion of the study area is densely covered with vegetation (Figure 4C). As part of Cebu Island, it is bounded on both sides with coastal areas, and most of central Cebu is low lying, except for the steep highlands (Figure 4D-E). Numerous lineaments and streams can be found in the area as well (Figure 4F-G). 


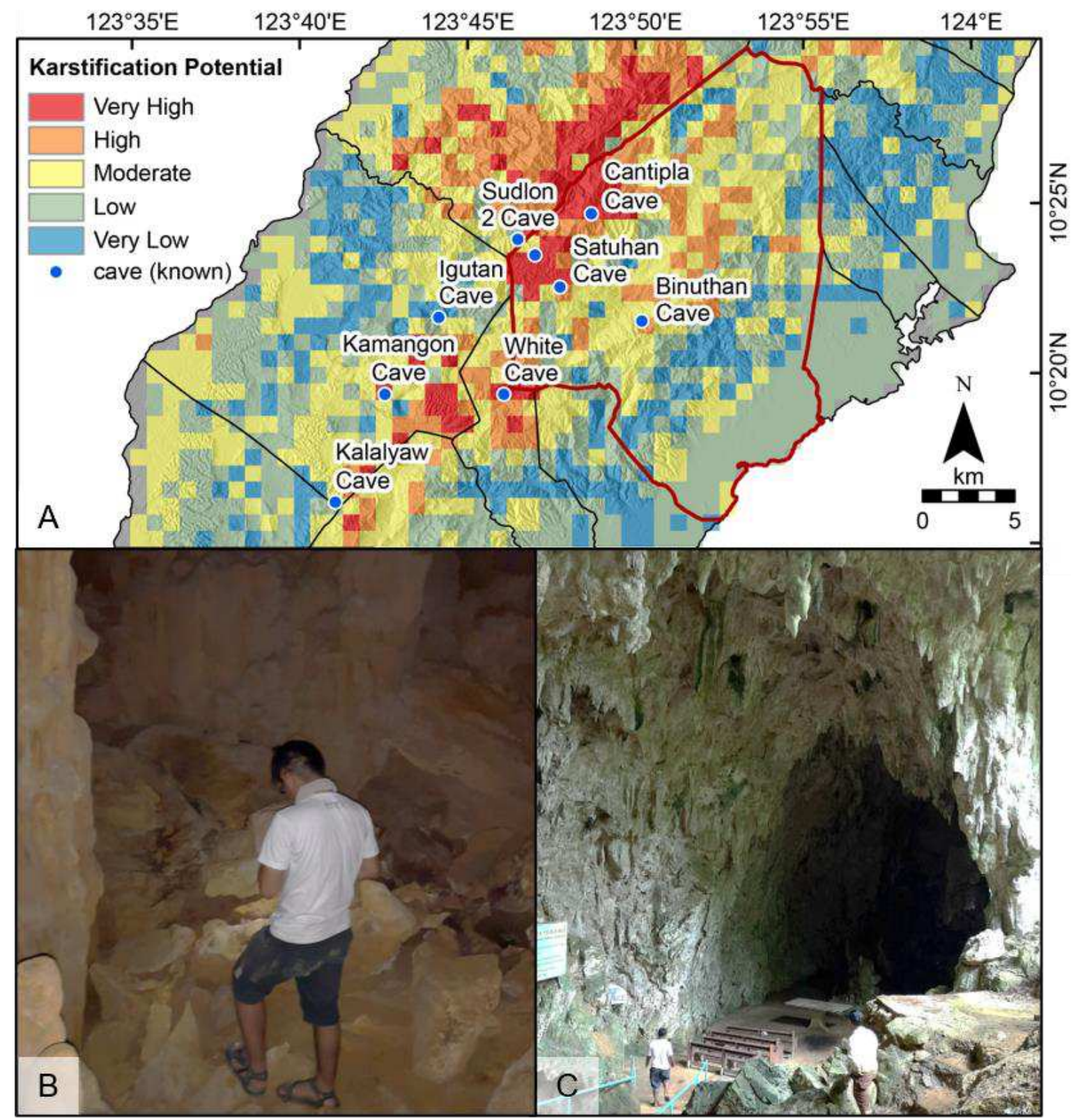

1 Figure 6. (A) Karstification potential map of central Cebu showing known cave

2 locations (blue dots) and the area of Cebu City (red borderline) which has almost 320

3 ground-validated sinkholes. Images of Cantipla Cave (B) and Satuhan Cave (C) are 4 also shown.

Cell Statistics is a simple tool in ArcGIS that uses the cell values of multiple

6 input rasters to calculate different statistics and produce a corresponding output raster

7 (ESRI, 2016). In this study, we used the Cell Statistics - Range function to find the

8 differences of the maximum and minimum values of each cell between each factor 
1 raster with the generated karstification potential map. The normalized values of the

2 differences, minimum of 0 (no difference) and maximum of 4 (5-1; minimum in one

3 raster and maximum in another), for each input layer was plotted in order to observe

4 their correlation with the generated karstification potential map (Figure 7A).
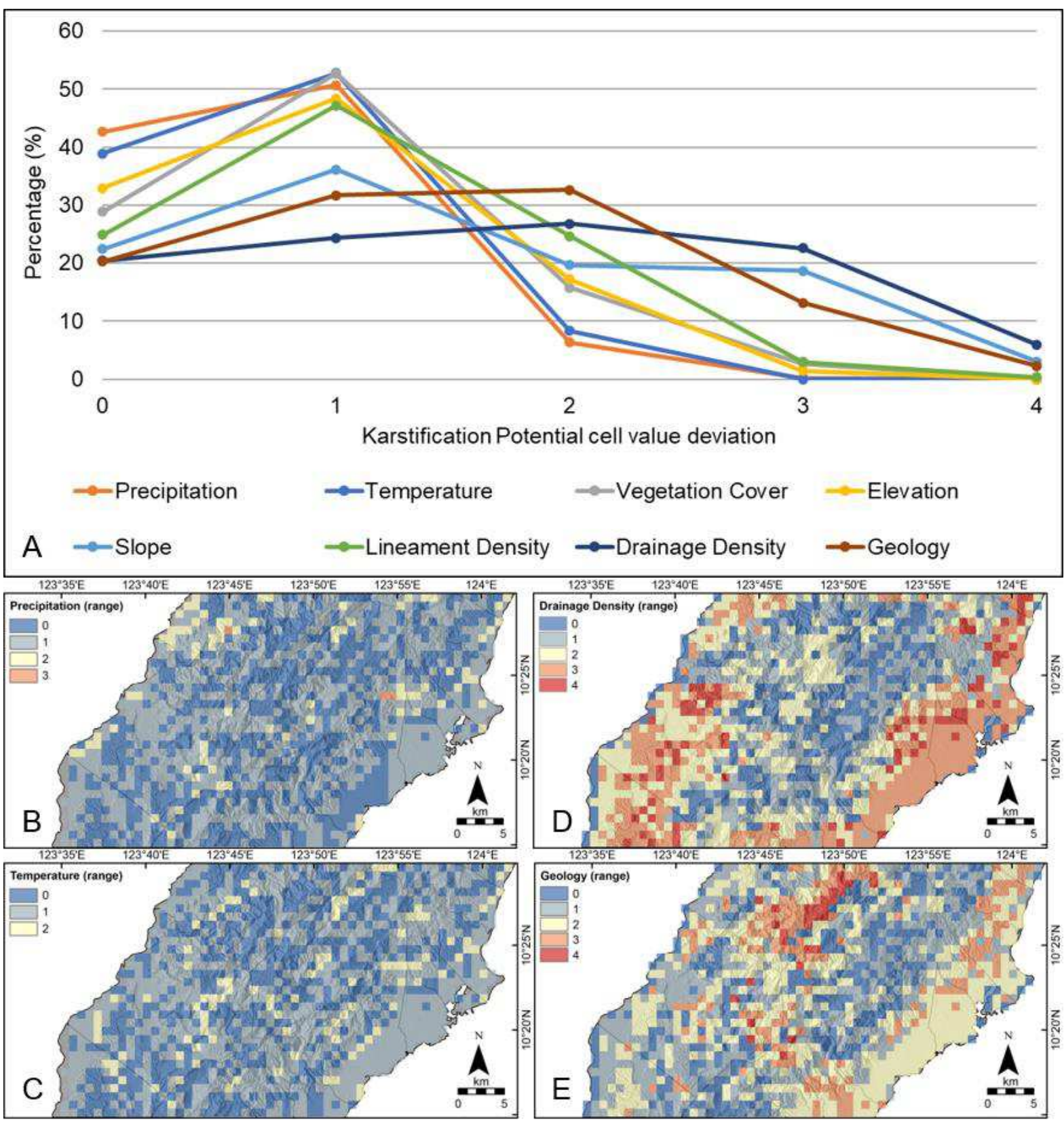

6 Figure 7. A. Cell Statistics (Range) multiple line graph plot showing the differences

7 between the cells from each input layer compared with the cells of the output layer.

8 The precipitation (B) and temperature (C) layers show a good correlation with the

9 karstification potential map, while the drainage density (D) and geology layers (E) 
1 appear to show the least correlation.

The karstification potential map strongly correlates with the precipitation (Figure 7B) and temperature layers (Figure 7C), and moderately with the elevation layer. Aside from their direct correlation with karstification potential itself, this strong correlation (Figure 7) can also be attributed to the high similarities between their own cell value distributions. Areas with high precipitation coincide with low temperature and high elevation; all these three factors are conducive to karst denudation. Conversely, the generated map least resembles the drainage density (Figure 7D) and geology (Figure $7 \mathrm{E})$ layers and reflects little resemblance with the slope layer, contrary to previous studies that highlight geology as the main factor with respect to karstification potential (Farrant and Cooper, 2008; Green, 2015). Such evaluation may be due to the fact that the employed analysis assigned equal weights to each factor, whereas varied weights are more likely in the natural setting (i.e., karst features cannot be formed in igneous and metamorphic units). The disparity between the resultant map from this study with the results of previous studies can then be resolved if areas underlain by nonsedimentary rocks are removed from the layers altogether, thus requiring pre-raster calculator filtering of each layer. This then removes the possibility for karstification to occur in non-sedimentary areas and makes geology the more dominant factor in promoting karstification.

The karstification potential map in this study suggests that the central Cebu highlands are the most prone to karstification. This implies that there is a higher possibility of karstification-related phenomena such as sinkhole formation, ground subsidence, and groundwater vulnerability occurring in these areas. Usually, typical karst mitigation practices such as grouting would lead to negative results and would aggravate the problem (Bonacci et al., 2009). Hydrogeological studies must be 


\section{Environmental Earth Sciences}

1 undertaken first prior to building on karst areas, so as to avoid threatening the quality

2 of the groundwater below (Hall et al., 1995).

\section{Conclusions}

Karstification potential is the degree of susceptibility of an area to karst denudation and can be affected by multiple factors. In this study, Raster Overlay Analysis in GIS was performed to evaluate the different climatic, topographic, geomorphological, and geologic factors contributing to the karstification potential of central Cebu. The following conditions are conducive to karstification: high mean annual precipitation, low mean annual temperature, very dense vegetation, very high elevation, gentle slope, very high lineament density, very low drainage density, and older limestone bedrock. Most of central Cebu area exhibits low to moderate karstification potential. Areas with moderate to very high karstification coincide with nine caves of known location. In this study, three factors show higher correlation with karstification potential: precipitation, temperature, and elevation. Vegetation cover and lineament density show moderate correlation, while drainage density, geology, and slope show little correlation. Using raster analysis with equal weighted overlay was used in this study as the first step in analyzing the karstification potential of a karstic area such as Central Cebu. However, karstification potential maps such as these are prone to misinterpretation, since digital elevation models (DEMs) usually only reflect a single or statistically summarized time frame. It is better to resolve these problems using varied DEMs, or DEMs or satellite images of varied temporal values.

It is recommended for geospatial analysis to be employed in order to further quantify the influence of each of these factors. Other predictive tools such as Analytical Hierarchy Process and Geographically Weighted Regression can also be used and compared with the equal weighted overlay approach of this study. It is also 
1 recommended for weighted overlay to have varied weights assigned to the different

2 layers as well as similarities in the scaling of values (i.e., same number of categories).

This study utilizes a simple method in assessing karstification potential as well as the method's validity in a manner that is easy to understand and communicate with lay audiences. It is also one of the few studies that have looked into karstification processes and evaluating karstification potential in the Philippines. Hence, aside from giving way to more advanced karstification studies in the Philippines in the future, this study also encourages the participation of the community in understanding and relaying information regarding karst and karstification processes.

\section{Acknowledgements}

This study was supported by the research project entitled Coastal Tectonics of

Central Philippine Islands and Its Implications for Seismic Hazards (under the program (03568-2016)) funded by the Department of Science and Technology - Philippine Council for Industry, Energy and Emerging Technology Research and Development (DOST-PCIEERD) and the National Institute of Geological Sciences (NIGS) Research Grant 2019 entitled Karstification Mapping of Central Cebu, Philippines using GIS. The authors would also like to thank R.B.C. Mendoza, L.P. Nawanao, Jr., A.J.T. Figueroa, and the Geology 215 class of 2018 (Cebu) for the data they contributed to this study. The authors also acknowledge the assistance and guidance of MGB personnel L.S.J. Manzano and her team in the analysis of sinkholes in Cebu City. The anonymous reviewers are thanked for their reviews that greatly improved this manuscript. The use of ArcGIS 10.3 was possible through the Environmental Systems Research Institute, Inc. (ESRI) Conservation Grant No. 497765 to N. Ramos. 
Environmental Earth Sciences

\section{$1 \quad$ References}

2 Active faults map: Province of Cebu, 2017.

3 Bakalowicz, M., 2005. Karst groundwater: A challenge for new resources. Hydrogeol. J. 13, 148-160. https://doi.org/10.1007/s10040-004-0402-9

Berhanu, K.G., Hatiye, S.D., 2020. Identification of Groundwater Potential Zones Using Proxy Data: Case study of Megech Watershed, Ethiopia. J. Hydrol. Reg. Stud. https://doi.org/10.1016/j.ejrh.2020.100676

Bonacci, O., Gottstein, S., Roje-Bonacci, T., 2009. Negative impacts of grouting on the underground karst environment. Ecohydrology. https://doi.org/10.1002/eco.90

Brinkmann, R., Parise, M., 2012. Karst environments: Problems, management, human impacts, and sustainability an introduction to the special issue. J. Cave Karst Stud. https://doi.org/10.4311/2011JCKS0253

Brook, G.A., Allison, T.L., 1986. Fracture mapping and ground subsidence susceptibility modeling in covered karst terrain: the example of Dougherty County, Georgia. L. Subsid. Proc. 3rd Symp. Venice, 1984.

Bureau of Mines and Geo-sciences, 1985. Geological Map of Cebu Quadrangle. $1: 50,000$.

Bureau of Mines and Geo-sciences, 1983a. Geological Map of Balamban Quadrangle. 1:50,000.

Bureau of Mines and Geo-sciences, 1983b. Geological Map of Buanoy Quadrangle. $1: 50,000$.

Bureau of Mines and Geo-sciences, 1983c. Geological Map of Pardo Quadrangle. $1: 50,000$.

Bureau of Mines and Geo-sciences, 1983d. Geological Map of Pinamungahan 


\section{Environmental Earth Sciences}

Quadrangle. 1:50,000.

Cahalan, M.D., Milewski, A.M., 2018. Catena Sinkhole formation mechanisms and geostatistical-based prediction analysis in a mantled karst terrain. Catena 165, 333-344. https://doi.org/10.1016/j.catena.2018.02.010

Chenoweth, M.S., 2003. Developing a spatial database for the interpretation of karst landscape and vegetation in the Jamaican Cockpit Country. ProQuest Diss. Theses. The University of Wisconsin - Milwaukee.

Corporal-Lodangco, I.L., Leslie, L.M., 2017. Defining Philippine Climate Zones Using Surface and High-Resolution Satellite Data, in: Procedia Computer Science. https://doi.org/10.1016/j.procs.2017.09.068

Doctor, D.H., Doctor, K.Z., 2012. Spatial analysis of geologic and hydrologic features relating to sinkhole occurrence in Jefferson County, West Virginia, in: Carbonates and Evaporites. https://doi.org/10.1007/s13146-012-0098-1

Doctor, D.H., Weary, D.J., Orndorff, R.C., Harlow, Jr., G.E., Kozar, M.D., Nelms, D.L., 2008. Bedrock Structural Controls on the Occurrence of Sinkholes and Springs in the Bedrock structural controls on the occurrence of sinkholes and springs in the northern Great Valley karst , Virginia and West Virginia 41003. https://doi.org/10.1061/41003(327)2

Dumperth, C., Rohn, J., Fleer, A., Wang, J.G., Xiang, W., Zimmermann, K., 2016. An easy approach to assess the susceptibility of a landslide by utilizing simple raster overlay methods: A case study on Huangtupo landslide (P.R. China). J. Mt. Sci. https://doi.org/10.1007/s11629-016-4011-6

Environmental Systems Research Institute, 2016. ArcMap 10.3. ESRI, Redlands, California.

Faivre, S., Pahernik, M., 2008. Structural influences on the spatial distribution of 
Environmental Earth Sciences

dolines, Island of Brač, Croatia. Zeitschrift für Geomorphol. 51, 487-503. https://doi.org/10.1127/0372-8854/2007/0051-0487

Farrant, A.R., Cooper, A.H., 2008. Karst geohazards in the UK: the use of digital data for hazard management. Q. J. Eng. Geol. Hydrogeol. 41, 339-356.

Fick, S.E., Hijmans, R.J., 2017. WorldClim 2: new 1-km spatial resolution climate surfaces for global land areas. Int. J. Climatol. https://doi.org/10.1002/joc.5086

Ford, D., Williams, P., 2013. Karst Hydrogeology and Geomorphology, Karst Hydrogeology and Geomorphology. https://doi.org/10.1002/9781118684986

Ford, D.C., Williams, P.W., 1989. Karst Geomorphology and Hydrology, Karst Geomorphology and Hydrology. https://doi.org/10.1007/978-94-011-7778-8

Green, T.B., 2015. Down the rabbit hole: Identifying Physical Controls on Sinkhole Formation in the UK, in: Proceedings of the 14th Multidisciplinary Conference on Sinkholes and the Engineering and Environmental Impacts of Karst. pp. 177187.

Hall, P.J., J. Mccusker, A., Bingham, C.T., 1995. Site investigation, monitoring, and successful landfill closure within a karst terrain. Karst geohazards Eng. Environ. Probl. karst terrane. Proc. 5th Conf. Gatlinbg. 1995. https://doi.org/10.1201/9780203749708-22

Hijmans, R.J., Cameron, S.E., Parra, J.L., Jones, P.G., Jarvis, A., 2005. Very high resolution interpolated climate surfaces for global land areas. Int. J. Climatol. https://doi.org/10.1002/joc.1276

Hubbard, D.A., 2001. Sinkhole distribution of the Valley and Ridge province, Virginia. Geotech. Environ. Appl. Karst Geol. Hydrol. https://doi.org/dangers naturels, effondrementVD

Hung, L.Q., Dinh, N.Q., Batelaan, O., Tam, V.T., Lagrou, D., 2002. Remote sensing 
and GIS-based analysis of cave development in the Suoimuoi catchment (Son La - NW Vietnam). J. Cave Karst Stud. 64, 23-33.

Leyson, O.O., 2017. Cebu City littered with 770 sinkholes | The Freeman. Freeman. Lumongsod, R.M.G., Ramos, N.T., Ramos, R. V., 2020. GIS-based spatial analysis of sinkholes in Cebu City, Philippines: insights on sinkhole occurrence and development, in: Proceedings of the 16th Multidisciplinary Conference on Sinkholes and the Engineering and Environmental Impacts of Karst.

Matus, C.L., 2013. 100 sinkholes found in Bohol after quake | Inquirer News. Inquirer.net.

Mondragon, D.M., Erram, M.M.B., 2018. MCWD: Metro Cebu to face water shortage in 7 years | Cebu Daily News. Cebu Dly. News.

Monroe, W.H., 1970. A glossary of karst terminology, in: US Geological Survey Water Supply Paper. https://doi.org/10.1016/0022-1694(71)90080-1

Moradi, S., Kalantari, N., Charchi, A., 2016. Karstification Potential Mapping in Northeast of Khuzestan Province , Iran , using Fuzzy Logic and Analytical Hierarchy Process ( AHP ) techniques Karstification Potential Mapping in Northeast of Khuzestan Province, Iran , using Fuzzy Logic and Analytica. https://doi.org/10.22059/jgeope.2016.58671

Müller, C., Jurgan, H., Porth, H., 1989. Paleogeographic Outlines of the Visayan Basin.pdf. Geol. Jahrb. B, 303-315.

Philippine Statistics Authority, 2016. 2015 Census of Population Report No. 1 - J Region VII - Central Visayas Population by Province, City, Municipality, and Barangay.

Porth, H., Müller, C., von Daniels, C.H., 1989. The Sedimentary Formations of the Visayan Basin, Philippines. Geol. Jahrb. B, 29-87. 
Environmental Earth Sciences

1 Rangin, C., Müller, C., Porth, H., 1989. Neogene Geodynamic Evolution of the Visayan Region. Geol. Jahrb. B, 7-27.

Santo, A., Del Prete, S., Di Crescenzo, G., Rotella, M., 2007. Karst processes and slope instability: some investigations in the carbonate Apennine of Campania (southern Italy). Geol. Soc. London, Spec. Publ. 279, 59-72. https://doi.org/10.1144/SP279.6

Santos-Yñigo, L., 1951. Geology and Ore Deposits of Central Cebu. Manila.

Seif, A., Ebrahimi, B., 2014. Using GIS to evaluate degree of karstification according to some important factors in carbonate rocks in Iran 107-126. https://doi.org/10.1007/s13146-014-0189-2

Shofner, G.A., Mills, H.H., Duke, J.E., 2001. A simple map index of karstification and its relationship to sinkhole and cave distribution in Tennessee. J. Cave Karst Stud.

Sweeting, M.M., 1979. Karst morphology and limestone petrology. Prog. Phys. Geogr. Earth Environ. 3, 102-110. https://doi.org/10.1177/030913337900300104

Wagner, J., 2013. Karst landscapes and karst features in the Philippines.

Whitman, D., Gubbels, T., Powell, L., 1999. Spatial interrelationships between lake elevations, water tables, and sinkhole occurrence in central Florida: A GIS approach. Photogramm. Eng. Remote Sensing.

Wilson, W.L., Beck, B.F., 1992. Hydrogeologic Factors Affecting New Sinkhole Development in the Orlando Area, Florida. Groundwater. https://doi.org/10.1111/j.1745-6584.1992.tb01575.x 
Environmental Earth Sciences

2 


\begin{tabular}{|c|c|c|c|c|}
\hline & Factor & Original Data & $\begin{array}{l}\text { Spatial } \\
\text { Resolution }\end{array}$ & Source \\
\hline \multirow[t]{2}{*}{ Climate } & Precipitation & $\begin{array}{l}\text { Average Monthly Precipitation } \\
\text { Data (1970-2000) }\end{array}$ & $30 s$ & Fick and Hijmans (2017) \\
\hline & Temperature & $\begin{array}{l}\text { Average Monthly Mean } \\
\text { Temperature Data (1970-2000) }\end{array}$ & $30 s$ & Fick and Hijmans (2017) \\
\hline Vegetation & $\begin{array}{l}\text { Vegetation } \\
\text { cover }\end{array}$ & $\begin{array}{l}\text { Philippine Land Cover Map } \\
\text { (2010) }\end{array}$ & $15 m^{*}$ & NAMRIA (2010) \\
\hline \multirow[t]{2}{*}{ Topography } & Elevation & IFSAR & $5 m$ & NAMRIA \\
\hline & Slope & IFSAR & $5 m$ & NAMRIA \\
\hline \multirow[t]{2}{*}{ Geomorphology } & $\begin{array}{l}\text { Lineament } \\
\text { density }\end{array}$ & faults & $5 m^{*}$ & \\
\hline & $\begin{array}{l}\text { Drainage } \\
\text { density }\end{array}$ & streams, drainage basins & $5 m^{*}$ & \\
\hline Geology & Geology & $\begin{array}{l}\text { Geologic Map of selected Cebu } \\
\text { Quadrangles }\end{array}$ & $5 m^{*}$ & $\begin{array}{l}\text { Mines and Geosciences Bureau (BMG, } \\
\text { 1985, 1983a, 1983b, 1983c, 1963) }\end{array}$ \\
\hline
\end{tabular}


1 Table 2. Range of values per category generated from raster data using manually

2 adjusted equal interval classification. Slope intervals were adopted from the

3 classification of Green (2015).

\begin{tabular}{lllllll}
\hline $\begin{array}{l}\text { Reclassification } \\
\text { value }\end{array}$ & $\begin{array}{l}\text { Precipitation } \\
(\mathbf{m m} / \mathbf{y r})\end{array}$ & $\begin{array}{l}\text { Temperature } \\
\left({ }^{\circ} \mathbf{C}\right)\end{array}$ & $\begin{array}{l}\text { Elevation } \\
(\mathbf{m})\end{array}$ & $\begin{array}{l}\text { Slope } \\
\left({ }^{\circ}\right)\end{array}$ & $\begin{array}{l}\text { Lineament } \\
\text { density } \\
\left(\mathbf{m} / \mathbf{m}^{2}\right)\end{array}$ & $\begin{array}{l}\text { Drainage } \\
\text { density } \\
\left(\mathbf{k m} / \mathbf{k m}^{2}\right)\end{array}$ \\
\hline $\mathbf{1}$ & & & & & & \\
& $<1500$ & $>27.5$ & $0-197$ & $>35$ & $0-0.11$ & $>2.0$ \\
\hline $\mathbf{2}$ & $1500-1700$ & $26.5-27.5$ & $197-393$ & $15-35$ & $0.11-0.23$ & $1.5-2.0$ \\
\hline $\mathbf{3}$ & $1700-1900$ & $25.5-26.5$ & $393-590$ & $10-15$ & $0.23-0.34$ & $1.0-1.5$ \\
\hline $\mathbf{4}$ & $1900-2100$ & $24.5-25.5$ & $590-787$ & $5-10$ & $0.34-0.45$ & $0-1.0$ \\
\hline $\mathbf{5}$ & $>2100$ & $<24.5$ & $787-984$ & $<5$ & $>0.45$ & 0
\end{tabular}

4

5 Table 3. Reclassification values of descriptive factors generated from vector data and

6 classified using manually adjusted equal interval classification.

\begin{tabular}{lll}
\hline Reclassification value & Vegetation Cover & Geology \\
\hline $\mathbf{1}$ & Very Sparse & Non-sedimentary rocks \\
\hline $\mathbf{2}$ & Sparse & Clastics sedimentary rocks only \\
\hline $\mathbf{3}$ & Moderate & Sedimentary formations with limestone \\
\hline $\mathbf{4}$ & Dense & Limestone (Middle Miocene - Recent) \\
\hline $\mathbf{5}$ & Very Dense & Limestone (Cretaceous - Middle Miocene)
\end{tabular}




\section{Declaration of interests}

$\nabla$ The authors declare that they have no known competing financial interests or personal relationships that could have appeared to influence the work reported in this paper.

$\square$ The authors declare the following financial interests/personal relationships which may be considered as potential competing interests:

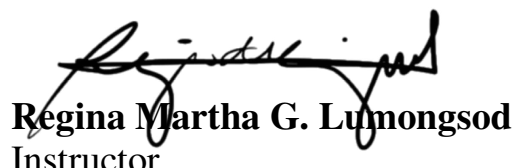

Instructor 